Terbit online pada laman web jurnal : http://e-journal.sastra-unes.com/index.php/JILP

\begin{tabular}{|c|c|c|}
\hline \multirow[b]{2}{*}{$\begin{array}{c}\text { Fakultas Sastra } \\
\text { Universitas Ekasakti }\end{array}$} & \multicolumn{2}{|c|}{$\begin{array}{c}\text { (JURNAL, ILMIAH LANGUE ANJ PAROLE) } \\
\text { VOLUME } 2 \text { NOMOR } 2\end{array}$} \\
\hline & $\begin{array}{c}\text { ISSN : 2581-0804 } \\
\text { (Media Cetak) }\end{array}$ & $\begin{array}{c}\text { E-ISSN : 2581-1819 } \\
\text { (Media Online) }\end{array}$ \\
\hline
\end{tabular}

\title{
GENERAL RETALIATION AGAINST THE ROMAN EMPIRE AS SEEN IN WILLIAM SHAKESPEARE'S CORIOLANUS
}

\author{
Ricky Hendria, Sherly Franchisca \\ Fakultas Sastra Universitas Ekasakti \\ *Corresponding Author: Sherly Franchisca \\ Universitas Ekasakti
}

\begin{abstract}
This reseacrh is titled "General Retaliation Against The Roman Empire As Seen In William Shakespeare's Coriolanus. In this research the author will discuss several issues, namely (1) How is Coriolanus's struggle in defending Rome's empire from enemy attacks? (2) What did Coriolanus do to avenge himself at the Roman empire? (3) What is the story of Coriolanus at the end of the story? the objectives of this research are (1) To analyze Coriolanus' life at the beginning of the story (2) To explain the cause of coriolanus to avenge his Roman empire (3) To study and explain how much Coriolanus's grudge to Rome to the tragic story he experienced.

The theory used in this research is literary psychology theory according to Sigmund Freud. This research uses a qualitative method. The object of research is the drama Coriolanus by William Shakespeare. Data sources are divided into two, namely primary data sources and secondary data sources. The primary data source is the drama script itself. Secondary data sources are text texts and several references related to research. The data collection technique is taking notes. The technical analysis of the data is descriptive analysis.

The results of the study show the following conclusions. First, the responsibility of a general in maintaining the sovereignty of his kingdom. Second, feelings of resentment arise when a struggle is not properly appreciated. Third, someone's revenge towards others can have fatal consequences and can even end in a tragic death.
\end{abstract}

Keywords: Against, Ravenge, Drama

(C) 2019Jurnal JILP

\section{INTRODUCTION}

Drama is part of literature. Literature is a work of art that tells the story elements by displaying expressions, emotions and language directly related to the lives of every human being; A drama is designed to be played on stage with real characters. Drama does not depend on the narrative, but its presentation uses speech and demonstration to make interactions that cause changes in character and resolve conflicts by the characters involved.

The background of the problems provides the reasons for the problem in this analysis. Therefore, the writer begins with describing the fact, problem, and solution to this writing. The fact in this analysis is that deep hostility between the Roman general Caius Martius with the Volsci warlord named Tullus Aufidius 
As the background of problems, reasons for choosing the problem of coriolanus' retaliation against Roman empire story, the drama, author of William Shakespeare, and literary work of the Coriolanus are described in systematic order. These background gives the foundation of the writer in writing this research.

Coriolanus is a drama adapted from the play by William Shakespeare. Coriolanus is taken from the true story of the legendary Roman leader, Caius Martius Coriolanus. The beginning of the film tells the story of the success of Captain Caius Matius Coriolanus who led the Roman army against Volscius rebel forces. At that time the Volscian forces led by General Tullus Aufidius were repelled by Coriolanus.

Coriolanus's success in the conquest Tullus Alfidius made him get a lot of praise. At the urging of his mother Volumnia and a number of senators, then Coriolanus ran for consul in Rome. Unfortunately Coriolanus's hard and superior views, as well as his plans to eradicate civil liberties, invited criticism and rejection. Thousands of Roma people reject Coriolanus's nomination as consul. The wave of rejection was compounded by the presence of two senates who provoked residents. Until finally Coriolanus had a strong opinion and the military decided to resign from candidacy. Many people do not expect Coriolanus to step back. After withdrawing from candidacy, Coriolanus decided to seclude himself. In solitude Coriolanus continues to be overwhelmed with resentment against the people of Rome. He felt wasted and his sacrifice so far towards Rome was not appreciated.

After being exiled from Rome, Coriolanus seeks out Aufidius in the Volscian capital of Antium and offers to let Aufidius kill him, to spite the country that banished him. Moved by his plight and honoured to fight alongside the great general, Aufidius and his superiors embrace Coriolanus and allow him to lead a new assault on the city, so that he can claim vengeance on the city which he feels betrayed him. Coriolanus and Aufidius lead a Voscilian attack on Rome. Panicked, Rome sends General Titus to persuade Coriolanus to halt his crusade for vengeance; when Titus reports his failure, Menenius follows but is also shunned. In response, Menenius, who has seemingly lost all hope in Coriolanus and Rome, commits suicide by a river bank. Finally, Volumnia is sent to meet with her son, along with Coriolanus' wife Virgilia and his son. Volumnia succeeds in dissuading her son from destroying Rome and Coriolanus makes peace between The Volscians and the Romans alongside General Cominius. When Coriolanus returns to the Volscian border, he is confronted by Aufidius and his men, who now also brand him as a traitor. They call him Martius and refuse to call him by his "stolen name" of Coriolanus. Aufidius explains to Coriolanus how he put aside his hatred so that they could conquer Rome but now that Coriolanus has prevented this, he has betrayed the promise between them. For this betrayal, Aufidius and his men attack and kill Coriolanus.

\section{'For $i$ will fight against my cank'red country, with the spleen of all the under fiends. (85)."}

From the above quotes the conversation and the Coriolanus statement to Aufidius so the writer choose this research because of Coriolanus' retaliation against on the Roman who made plans for the war to their own empire.

\section{RESEARCH METHODS}

The writer divides the method of research into the method of collecting data, method of the data analyzing procedure, technique of data collecting, and technique of the data analyzing procedure. This method becomes the foundation for the writer in the analysis drama, starting from collecting the material to be analyzed and the procedure in analyzing the drama. I used qualitative research for the collecting data.

\begin{abstract}
Creswell (1998:41) say that:
"one undertakes qualitative research in a natural setting where the researcher was an instrument of data collection who gathers words or pictures, analyzed them inductively, focuses on the meaning of participans, and discribes a process tha was expressive and persuasive in language."
\end{abstract}


Qualitative method involves studying a small number of individuals or sites, it was conducted in a natural setting, it was focused on participant perspectives, it had the researcher as the primary instrument for data collection. Besides that, it uses multiple methods of data collection in the form of words or pictures, it involves extended firsthand engagement. Other than that, focuses on centrality of meaning for participants deals with dynamic systems, it deals with wholeness and complexity and assumes that change was constant, it was subjective, and it uses an emergent design.

\subsection{Method of Collecting the Data}

The data collecting procedures is focused on the process of the writer collect the data. In the collecting data the writer applies library research. It means that the writer applies the data which the writer takes from library. Pradopo in Metodologi Penelitian Sastra (2001:153) states:

Penelitian pustaka adalah observasi yang dilakukan dalam pustaka, dimana penulis mendapatkan data dan informasi tentang objek penelitian melalui buku dan media audiovisual yang berhubungan dengan topic.

The library research is the observation that is executed in the library, which the writer gains the data and information about his object through the books and other audiovisual equipment that related and relevant to the topic. (translated by writer)

Through this library research activity, the writer gains some information to understand the problem. In order to gain more information, the writer also executes the internet research as to support the data from library research, the data is received in files form

Activity of data collection is a very important in any form of reserch in this research.The method of documentations to find data about the things or variables. The instrument of this research is the writer as the key or main instrument that spend a deal great or time reading and understanding the drama

\subsection{Method of Analyzing the Data}

In analyzing the data, the information from data collection is processed and presented in from thesis. In the application, the writer used structural method. According to Pradopo (2001:69). "the researcher hase role to explain literary work as a structure based on the elements that build them". From this quotation, structural method has fuctions to explain the intrinsic elements of literary work.

The procedure starts by reading the main source of analysis, which is the drama Coriolanus by William Shakespeare. The in order to have the audio visual understanding, the writer finds the movie Coriolanus. After understanding the story, the procedure moves to find the intrinsic elements in the drama, which are plot, theme, characters, setting of place, setting of time, and poin of view. After the data are organized, the writing is composed based on standard of thesis writing.

\subsection{Technique of Collecting the Data}

The technique of collecting the data in this reseaarch is library research; the data from both primary and secondary sources are collected and recorded in the short of document as evidence. The techniques of data are follows :

a. Reading the books and searching on internet for collecting the data,

b. Watching the movie,

c. Taking notes of important data from both primary and secondary sources,

d. Arranging the data into several parts according to its classification,

e. Selecting particular that are considered important and relevant for the analysis, and

f. Drawing the finding based on the data analysis

\subsection{Technique of Analyzing the Data}

The data analyzing procedures concern with the ways of the writer to conduct the analysis of the data. In this research the writer applies structural technique. It looks the internal factor of literature that covers the internal element of literary work such the actions of the main characters. Pradopo (2001:54) states that:

Peneliti bertugas menjelaskan karya sastra sebagai sebuah sruktur berdasarkan unsur-unsur yang membentuknya.

The researcher has a chance to explain literary work as a structure base on the element that formed them (translated by writer).

From the explanation above, structural technique has two functions which explain the 
internal factor of literature. The primary data is taken from drama itself, the writer tries to analyze it by using the information in form of quotations based on the drama itself. In doing this research, the writer starts by analyzing some intrisic elements of this drama, after that tries to find extrinsic element which becomes the basic of the problem that will be analyzed.Further, Abrams and Harpham (2009:22), the definition of character is:

$$
\begin{aligned}
& \text { The person presented in dramatic } \\
& \text { or narrative work, who are } \\
& \text { interpreted by the reader as being } \\
& \text { endowed with moral, dispositional, }
\end{aligned}
$$

\section{RESULTS AND DISCUSSION}

Action begins noisily with a civil disturbance, prompted by a food shortage. This citizenry is 'resolved rather to die than to femish'. As frequently happens, an individual is identified as rhe source of the trouble. In this instance the ritual object of hatred is Caius Martius; no perverse choice, give the contempt which he reveals for the common people later on. The problem reduces to: 'Let us kill him, and we'll have corn at own price' (I.1.4-5). But the tensions exhibited in this opening scene extend beyond the immediate problem of food shortages. There is the rift between patricians and plebs - quibbles on poor (inferior as well as impoverished) and good (morally as well as financially sound) showing that the citizens are astutely aware of patrician evaluation (I.1.5-6). In this same speech, too, the First Citizen notes not only how the well to do are too niggardly to relieve the poor, but how they wish to preserve poverty as a means of emphassing their own affluence.

What Shakespeare shows us here is not just that empty bellies are prime movers to revolt. Other conditions have to be satisfied first. Whereupon they will be apt to start pondering their role in the social structure. But Brecht, in this 'Study of The First Scene of Shakespeare's "Coriolanus" (p.253), properly emphasises 'how hard it is for the oppressed to become united'. Their misery will united the once they have identified their oppressors. "but otherwise their misery is the wretched crumbs from each other's mouths'. Futher, they are trapped in the ideology and emotional qualities that are expressive in what they say, the dialogue, and what they do in the action.

It means the character has the leading roles in a literary work and the character is the form of media in which the author uses in expressing human behaviour. By means of expressing the character behaviour, the readers can understand the story by seeing the dialogue, the action and the problem of the character.

of the governing class which insist that 'revolt is the unnatural rather than the natural thing'. It is just this process, in all its complexities and confusions, that shakespeare puts before us.

The text of the 1623 Folio confuses speakers in this scene, but those modern commentators who discern identifiable personalities emerging in the debate are surely right. Thus the second Citizen is uneasy about proceeding against Caius Martius in view of the 'services he has done for his country' (I.1.25-30). But the First Citizen believes that martius is motivated by price rather than love of country. That he is speaking from knowledge rather than scoring a debating point is apparent from the alert way in which he adds Caius's further motive of pleasing his mother. But the Second Citizen's resistance to moving against an autority figure is dogged, however illogical: 'What he cannot help in his nature, you account a vice in him' (I.1.40). Unable to country the First Citizen's accusations, he feebly insistts that at least martius is not covetous. Perhaps not, but he is soon confessing that he is drawn towards the sister sin of envy (I.1.229).

Meanwhile, progress towards the Capitol is stayed by the arrival of Menenius: ' one that hath always loved the people', says the Second Citizen. This sound unctuous, but even the First Citizen allows Menenius to be honest. It is really the mark of the latter's capacity to deceive. Latter on, when he has a change to asess the opposition at first hand, this second Citizen - apt

Jurnal JILP (Jurnal Ilmiah Langue and Parole) Vol. 2 No. 2 (2019) ISSN : 2581-0804

This work is licensed under a Creative Commons Attribution-NonCommercial 4.0 International License. 
to think the best of people until Coriolanus. So shakespeare is emphassing, in this sudden turnabout, the remarkable fair-mindedness to be found among these citizens.

Menenius is the ideal spokesman for the governing class during this emergency. $\mathrm{He}$ is a shrewd operator, awere that people are flattered by the attentions of those they recognise as their social superior. The iron first is concealed by the velvet glove of an easy, femiliar manner. But the message is clear about the futility of opposing the ship of state, divinely instituted and powered. At the helm are the patrician senator "who care for you like fathers, when you curse then as enemies' (I.1.70). While not swallowing that, the First Citizen is at least prepared to hear the bellyfable.

This resorts to the old notion of the body politic, the state as living organism. Its essential message is hierarchical. (that it is analogous to the contemporarry view of the family with its patriarchal head is worth bearing in mind in connection with Caius Martius's family situation). Menenius's picture of the body's members rebelling against the belly (the rulling class) provides an effective parable about the interdependence of the various elements in the state. The heckling and good-natured banter which accompany Menenius's fable shed light on his character as well as making the scene dramatically interesting. He is quick on his feet, able to keep up a genial front, and generally adept at cooling tempers. But there is more tact of manner than matter. He uses a belly-fable to listeners whose bellies are painfully empty. He pictures a system of food distribution from the centre when that is conspicuously lacking. In short, his friendly manner conceals a patronising contempt. He is the politican, well aware that in politics, manner is more important than matter. Unhampered by any notions of social justice he can distract his stage audience from the reel issues with a piece of pithy irrelevance.

Menenius's contempt appears naked when he declares that 'Rome and her rats are at the point of battle' (I.1.160-165). Rome is identified with the rulling class alone; the citizens are rats which plague the state. And he adopts another characteristic ploy in isolating the First Citizen as ringleader or 'great toe of this assembly' (I.1.155-160). Yet he offers a clear contrast with Caius Martius who now appears. At least Menenius tries to talk with the plebs. Martius Flatly declares:

He that will good words to thee, will flatter

Beneath abhorring. (I.1.170)

At this point, surely Menenius is the more dangerous to the plebeian cause. Martius is aloof, a clearly identifiable enemy. But Menenius is liked for his man-to-man affability. Where Martius is mereky frighten- ing, Menenius will flatter the plebs into self- betrayal.

To Martius the citizens seem equally detestable in place and war: 'the one affrighthts you, The other makes you proud' (I.1.168). His fierce indictment is the less persuasive since what he sees as an undifferent-tiated mass has been presented to us by Shakespeare as a collection of individuals. He is furious that they dare to

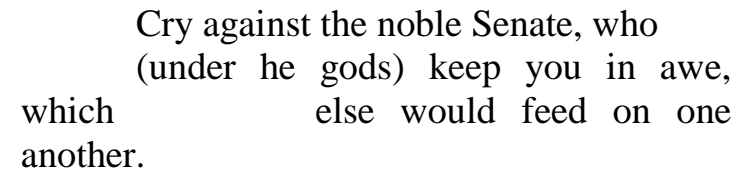

Cry against the noble Senate, who (under he gods) keep you in awe, which else would feed on one another.

(I.1.185-190)

That any feeding on one another would have been precipitated by the Senate's failure to feed them is an unperceived irony. Indeed, Martius disdains to ask the citizens directly about their grievances.that he is fully aware of them becomes quickly apparent. But Menenius tells him anyway, in phrases celarly aimed at the plebs rather than Martius:

(They want) corn at their own rates, whereof they say the city is well

stor'd. (I.1.190-195)

$\mathrm{He}$ is giving nothing away and Martius fastens on to the same phrase:

$$
\begin{aligned}
& \text { Hang 'em! They say! } \\
& \text {...They say there's grain enough? } \\
& \text { (I.1.195) }
\end{aligned}
$$

$\mathrm{He}$ is outraget at their presumption, which he would repay with the sword:

Would the nobility lay aside their ruth,

And let me use my sword, i'd make a aquary 
as

With thousands of these quarter'd slaves, high

As i could pick my lance. (I.1.200-205)

The verb 'to pick', as used here, is virtually with 'to pitch'. The terms 'quarry' and 'quarter'd' work effectively because their primary application is to the hunting field rather than that of battle. Hence a 'quarry' is the pile of deer killed by hunters. To speak thus of the citizens associates with that animal name-calling in which Coriolanus and his fellows are wont to indulge at the expense of social inferiors.

But this is an add performance. Coriolanus says himself that the citizens are no fighthers, so why is he so eager to eager to exercise his skills on them? This is a parody, even self-parody, of the vaunting super-hero. But as such it is a contribution to the play's critical consideration of the nature of heroism.

However, it now becomes clear why coriolans is so incensed against the citizens. When menenius points out that his own artful words have sufficiently tamed this group of citizens, martius announces that another has won concessions to the extent of five Tribunes being appointed to represent the plebs in the Senate. This, he believe, is the thin end of a wedge directed against class privelege:

The rabble should have first unroof'd the city

Era so prevail'd with me. (I.1.220223)

News that war with the volsce is imminent pleases Martius. He sees it as a means of killing off some of rome's superfluous citizenry. So he recognises one half of a social contract: the duty which that citizenry has to fight for Rome. But he and his peer have no sense of reciprocal obligation. The senator have only yielded to pressure in giving the citizens some kind of representation.

Shakespeare has set up a sharp contrast between the citizens and martius. Their estimate of him is accurate; his of them a tange of ugly prejudices. If some of them are at fault in wishing to dispose of minate violence. He would rather see the very fabric of rome distroyet that yield an inch to those he holds inferior. This Martius's allegiance comes into view, casting a shadow forward to the events of Act IV, in his remarks on the Volcian leader Aufidius. $\mathrm{He}$ adminers the latter immoderately as fighter, especially as opponent:

Were half to half the world by the'ears, and he

Upon my party, I'd revolt to make

Only my wars with him (I.1.235-240)

Already it is clear that martius's military motives are personal, not patriotic.

The scene edds with the newly-appointed people's Tribunes, hitherto ignored, left on stage to assess Martius and his prospects the war. They offer a shrewd analysis of the advantages likely to accrue to him as second-in-command, under Cominius, of the Roman force

Coriolanus takes his leave of family and friends at the gates of Rome. He is impatient of the women's tears and resorts to his usual style of disparagement of the people: 'the beast/with the many heads butts me away'. He points out how 'common chances common men could bear', but he caught

Will or exceed the common, or be

With cautelous baits and practice.

(IV.1.30- 35)

But ironically this will prove a false antithesis. While he may 'exceed the common' this will not save him from those 'cautelous baits'.

The extent of his friends' loyalty is apparent Comminius's readiness to accompany him for a month. On the other hand, Coriolanus's loyality consist in being true to himself. It is in this way that personal integrity and his betrayal of Rome may be reconsiled. There is anticipatory irony but no deception when he declares on parting:

While I remain above the ground you shall

Hear from me still, and never of me aught

(IV.1.50-55)

But what is like me formerly.

Coriolanus and aufidius meet for the first time without drawn swords. Coriolanus's attempts to enter aufidius's house, where a party is in progress, are thwarted by servants due to his unprepossesing appearance. But his looks are more than uncouth. His exchange with the Third 
Servant suggests something deeply siniter. If his blood-soaked appearance in I. vi had concealed his identity, making him seem the god of battles, he now has the look of Death. But there is somothing of Death the jester here, full of bitter ironies and dark absurdities. In answer to the servant's question, he claims to dwell 'Under the canopy' in the city of kites and crows', the carrion-feeders

$\mathrm{He}$ quibbles on 'suname' and 'service' for which it was given. It ironically links with the service which he has declared himself ready to offer at the end of the preceding scene, service now to the erstwhile enemy. It is the very last word of scane iv, and it is picked up in the first line of the next when it is trivialised as the service provided at table. The two kinds of service, of domestic attendant and of warrior, become confused with sexual service during the exchange with the Third Servant:

CORIALANUS : I serve not thy master.

THIRD SERVANT : How, sir! Do you meddle wih my

master?

CORIOLANUS : ay; 'tis an honester service meddle than to with

.(IV.1.40-45)

thy mistress

There is an echo of that image of adultery used by nicanor to point up Rome's vulnerability. In the process it raises the teasing question of whether the service which Coriolanus is about to offer is more honest than that of adulterer.

Coriolanus's lengthy speech to Aufidius is profoundly revealing in this respect. Having disclosed that he is Coriolanus, he complains that the name is all the reward he ever got from his 'thankless country'. Loot never appealed to him; but this suggests that mere abstractions were insufficient, too. What remains is senatorial office, with its power and authority, implicitly seen here as a proper return for enduring the hazards of war.

We now fully understand how Coriolanus's extreme bitterness at having been thwarted in his bid for office has spilt over into hatred of his fellow patricians. It is these 'dastard nobles' who conferred on the plebs the power to banish him. They, too, are culpable, so his proposed vengeance wil encompass them. If Aufidius will join him, he will fight

Against my canker'd with the spleen

Of all the under Fiends. (IV.5.85-90)

Aufidius responts by embrancing Coriolanus ecstatically. Like Coriolanus when he hugged Cominius on the battlefield, Aufidius thinks back excitedly to his wedding night:

More dances my rapt heart

Than when I first wedded mistress saw

Bestride my threshold. (IV.5.110-115)

These bridal occasions have sometime been perceived as a refined and delicate form of combat. Conversely the emotions of battle are somewhat akin to the sexual impulse. Aufidius confesses to something like an infatuation with Coriolanus; each night he has

Dreamt of encounters twixt thyself
and me $^{-}$
We have been down together in my
sleep, Unbuckling helms, fisting each
Other's throat -

And wak'd half dead with nothing.

(IV.5.115-120)

The affinity with erotic dreams needs no emphasis. Now the prospectof this union in battle produces a heated intensity in which sexual and military cravings and urgencies coalesce. Their joint energies will be released in the rape of Rome.; the sexual violence is clear in that image of 'pouring war/Into the bowels of ungrateful Rome'.

These two leave the stage to the servingman, the mood dropping from high drama into comedy. But in addition there is commentary on what has taken place, and a parodic restatement of the protagonist military ethic. The servants marvel at the power which is exuced by Coriolanus, or crudely demonstrated by his strenght of arm. They warily consider him the fighting superior of their own master.

The Third servingman enters with the news that Coriolanus is being feted, given a seet of honour at the head of Aufidius's table: 'Our general himself makes a mistress of him, sanctifies himself with's hand, and turns up he white o' th' eye to his discourse'. The play of hands and the attentiveness to Coriolanus's every 
word are tokens of the lover. The picture is a vivid replay of what we have already seen enacted between the protagonists. Those intimations of cruelty which the psychologist detect beneaath the toyings of courtship will achieve an awesome reality when this couple moves on Rome. War, says the Second Servingman, pursuing the image, is 'a ravisher'. Yet the naked display of force is given moral ascendancy over its opposite, for 'it cannot be denied but peace is a great maker of cuckolds'.

The moral contrast is pursued as the First Servingman offers the paradox that peace 'makes men hate on another'. It is expressed as an amusing conundrum, solved without difficulty by the Third Servingmen: 'because they than less need one another'. Yet the humour disguises a real moral dilemma, one often considered in relation to the Second World War blitz. The solidarity which that outside threat achieved amongst the British people could never be recaptured in the years of the peace which followed.

The case for war is put very plainly. When it arrivs, says the Second Servingman.

We shall have a stirring world again,

This peace is

Nothing but to rust iron, icrease tailors, and breed

Ballad-makers.

FIRST SERVINGMAN: let me have war, say I. It exceeds peace as

far as day does night; its sprightly walking, audible, and full of vent. Peace is a very apoplexy, lethargy; mulled, deaf, sleepy, insensible; a getter of more bastard children than war's a destroyer of men. (IV.6.80-85)

War for Coriolanus is more than a bracing activity. The conflict with the Volsces had seemed a way of disposing of the plebeian threat. Now war is to be the surgery practised directly on his 'canker'd country'. So far from being a necessary evil, a regrettable means to a desirable end, war is seen as a sourse of moral and spiritual renewal. Its destructive aspect is nothing compared with the corrupting ease of peacetime. Indeed, the destructive aspect is part of war's appeal. In Antony and Cleopatra, written about the same time as Coriolanus, Sahkespeare describes death's coming in terms of 'a lover's pinch/Which hurts and is desir'd'. Here the same powerful fascination is ascribed to war. That it is perverse fascination, that the dynamic creativity of its exponent is in truth a destructive futility, is underlined by putting this martial philosophy into the mouths of several comic servingmen. That they have been sharp enough to see the absurdity of Aufidius's feting of Coriolanus makes no difference to the fact that we must look twice at the wisdom of jesters.

Aufidius plots against Coriolanus out of envy. Now that Coriolanus has provided him the pretext, he seeks to undermine his popularity, for it has rankled to seem 'his follower, not partner' (V.6.35-40). Aufidius makes his bid throuht the nobles, for the common people still hero-worship Coriolanus. (their attitude has been strangely at variance with that of their Roman counterparts in this respect.) there is some ambiguity about whether the action is set in Aufidius's home town, Antimun (V.6.50-55) or Corioles, scane of Coriolanus's greatest tri triumph. Aufidius marvels that people, 'whose children he has slain; should cheer Coriolanus so heartily (V.6.55-60).

When Coriolanus enters with his troops, his speech proclaims the military advantages and financial profits he has gained for the Volsces' slurring over the attendant betrayal: soldier,

Hail lords, I am return'd your

No more infected with my country's love

Than your great command. You are to know

That prosperously I have attempted, and

With bloodly passage led your wars even to

The gates of Rome. Our spoils we have brought home

Doth more than counterpoise a full third part

The charges of the action. We have made peace

With no less honour to the Antiates

Than shame to th' Romans; and we here deliver, patricians,

Subscrib'd by th' consuls and 
Together with the seal o' th' senate, what

We have compounded on. (V.6.7080)

Stanley Hussey makes sharp point about this speech. These generalities and subordinate clausee contrast with Coriolanus's previous modes of utterance: 'He has finally learned to talk like a politician, to present a defead as a victory, but in so doing he debases himself. For all his previous inflexibility, we admired him more when spoke like a Roman' (The Literary Language of Shakespeare, London, 1982, p. 178). The very language he uses exposes the ambiguity of his action in yiel to his mother. Humanity and hypocrisy have somehow become entwined.

But this is just for our ears. Aufidius register none of this complexity, only the chance to destroy his rival. He refuses to address him by his 'stol'n name/Coriolanus, in Corioles', calling him traitor instead. It is a tactic which the Tribunes have already put to affective use, and Aufidius follows up by tauting him as 'boy of tears'(V.6.100-105). The sting in this, as Harry Levin points out, stems from the fact that, in heeding his mother's persuasions, 'the strong man becomes again - as it were - a child' (Shakespeare an d the Revolution of the Times, $\mathrm{p}$. 195). But there is immaturity in Coriolanus, but then with a monstrous lack of tact, recalls how

Like an eagle in a dove-cote, I

Flutter'd your Volscians in Corioles.

(V.6.110-115)

In thus reminding the people of the painful bereavements which he has caused them, he is doomed. The conspirations stab him to death and Aufidius tramples the corpse, moving even the Volcian nobles to protest :

Thou hast done a deed whereat valour will weep. (V.6.132)

For all the harm Coriolanus has done them in the past, and their present sense of betrayal, they recognise his exceptional qualities :
Let him be regarded

As the most noble corse that ever herald

Did follow to his urn. (V.6.140-145)

Or, more cynically, perhaps they reflect that heroes may be praised safely when dead. Perhaps there is a mixture of cynicism and something more. Aufidius, too, changes his tune:

My rage is gone, 150)

And I am struck with sorrow. (V.6.145-

He helps to bear off the body that he has abused moments before, vowing that Coriolanus 'shall have a nobles memory', a monument commensurate with his stature. But what is this nobility, which can accommodate the betrayal of both homeland and that of adoption? Nor does the confusion end there since paradoxically, and in spite of himself, this double apostate has contrived to die for his country. Aufidius's words form a fittingly enigmatic conclusion, since he is hardly to be reckonned an impartial jugle of greatness or nobility.

Wilson Knight's succinct evaluation of Coriolanus has him 'In war a man of death, in peace ... a a social poison'. Yet finally he is 'purified' through an act of love (the Imperial theme, methuen, 1965,p.181, 197). But if Aufidius discerns nobility in his enemy, it is not in this newly revealed capacity for love but in his uniquely destructive capability. The play ends with a dead march, like Hamlet. But unlike Hamlet, indeed uniquely in mature Shakespearean tragedy, it offer no signs of renewal, no Fortinbras to take up the reins and restore order out of chaos. Instead, with or without Coriolanus, this world remains stubbornly out of joint. 


\section{CONCLUSION}

\subsection{Conclusions}

After analyzing the drama Coriolanus by William Shakespeare, the writer make the conclusion as follows :

1. Coriolanus is a very reliable general in Rome. He has a good strategy in fighting. With the courage and responsibility he had towards Rome, not even if his enemies escaped his hands. Even Aufidius whose archenemies continued to recognize the greatness of Coriolanus in fighting until the Roman empire was safe from enemy.

2. Since the Roman Empire ignored the concern of Coriolanus that had been done so far, he decided to leave Rome. In addition, the senates influenced the people to hate Coriolanus. Finally the revenge appeared and Coriolanus joined Aufidius to attack the Roman Empire.

3. When Coriolanus and Aufidius had planned to attack Rome, various travelers arrived from Rome to ask Coriolanus to stop the attack. But Coriolanus still ignored the offer. Until finally, the mother, wife and son of Coriolanus themselves meet Coriolanus. Coriolanus decided to cancel the attack and sign an agreement in Rome. When Coriolanus returned from Rome, Aufidius became angry at Coriolanus because he felt that Coriolanus had violated their agreement which had been agreed at the beginning. The end of Aufidius and with its members killed Coriolanus.

\subsection{Suggestions}

In analyzing the drama, the writer is realizes that has not covered all internal aspects yet, such as theme, setting, characters and many more. The writer also only analyzes the external. However, this analysis might not be perfect, so the writer wants certain inputs and critics from the readers in perfection of this writing. Mistakes and weakness still happened in many aspects such as method, analyzes, and discussion. Positive suggestion and criticism still the writer needed to make the next study better. Thus, the writer hope for those who have the desire and love of literary works to be motivated to develop other aspect especially in analyzing the drama, in order to be useful to increase their knowledge of drama in English literature 


\section{Bibliography}

[1]Abrams. M. H. and Harpham G. G. 2009.A Glossary of Literary Terms. London: Wadsworth

[2]Atkinson, R.C And Hilgard, E.R. 1996. Pengantar Psikologi. Jakarta : Erlangga

[3]Bruce, Yvonne. 2000. "The Pathology of Rhetoric in Coriolanus" . English Faculty Publications.

84. https://engagedscholarship.csuohio.edu/cle ng facpub/84 on december 15th. 2018 at $08.17 \mathrm{PM}$

[4]Creswell, John W. 1998. Qualitative Inquiry and Research Design: Choosing Among Five Traditions. London: Sage

[5]Daiches, David. 1990. Critical theories to literature. Singapore: Singapore Publisher Ltd

[6]Freud. Sigmund. 1856-1939. Understanding the Id, Ego, and Superego in Psychology. (n.d.). - For Dummies

[7]Fromm, Erich. 1992. The Revision of Psycholoanalysis. New York: Open Road
[8]Kennedy, X. J and Dana Gioia. 1995. An Introduction to Fiction, Poetry and Drama. New York: Happer Collins

[9]Lehnhof, Kent. 2013. "Acting, Integrity, and Gender in Coriolanus," Shakespeare Bulletin 31: 353-73. DOI:10.1353/shb.2013.005 on december 15 th. 2018 at $08.15 \mathrm{PM}$

[10]Luxemburg. Jan Van. et.al. 1995.Pengantar Ilmu Sastra. Gramedia: Jakarta

[11]Marie. 2016. Drama: A Guide to the Study of Plays. New york: Open Road

[12]Pradopo. Rahmat Djoko. 2001.Metodologi Penelitian Sastra. Yogyakarta:Hanindita Ghasa Widia

[13]Shaw M.E and Constanzo P.R. 1998. Theories of Social Psychology. Tokyo: McGraw Hill

[14]Wellek, Rene and Austin Warren. 1996. Theory of Literature, New York Harcourt Brace and World Inc

[15]Williams. Raymond. 1996.Modern Tragedy. London: Chatto \& Windus 